\title{
RURAL DEVELOPMENT AND LOCAL ACTION GROUPS IN SLOVAKIA: INTERNATIONAL AND INTRANATIONAL COM- PARISONS
}

DOI: https://doi.org/10.18509/AGB.2018.04

UDK: 332.1:911.373(437.6)

\author{
Vladimír Székely ${ }^{1}$ \\ ${ }^{1}$ Institute of Geography Slovak Academy of Sciences, Slovakia \\ Corresponding author: szekely@savba.sk \\ Submitted: January 2017, Accepted: May 2017, Published: October 2017
}

\begin{abstract}
The differentiated speed with which a new idea on rural development paradigm change is adopted and accepted is depending on the number of years of membership in the EU. Slovakia (since 2004), Austria (since 1995) and Ireland (since 1973) are compared to each other from the viewpoints of number, size and significance of the Local Action Groups registered for the period 2007 - 2013. In the context of intranational comparison 29 registered LAGs constitute for us different territorial units which we are comparing according to their sizes (number of inhabitants and municipalities, geographical area) and their relations to administrative boundaries with the stress on the description and explanation of the extreme cases.
\end{abstract}

Key words: new paradigm of rural development, LEADER programme, Local Action Groups, Slovakia;

\section{Introduction}

Rural areas in the whole world are changing, particularly with respect to demography, diversification, and strengthening links to national and global economies [1]. As a reaction on this process the forms of rural policies, particularly in the Europe, are also under the influence of the dynamic changes. The shifts of concepts of rural development ("new paradigm of rural development") are going from sectorial focus to the spatial one, and/or from the top-down development strategy to the bottom-up one [6]. The European Union's 'LEADER' programme (an acronym of Liaisons Entre Actions de Développement de l'Economie Rurale), as integral part of Rural Development Programme (representing the place-based bottom-up approach of rural development), is perceived as the important, spatially oriented instrument of current rural policy [12], and Local Action Groups, groups of public and private partners (public-private partnerships) from the rural territory, are the mainstay of

the implementation of this developmental initiative.

Though the professional and scientific literature pays great attention to multiple general and national aspects of LEADER programme and LAGs (implementation, functioning, evaluation and presentation in mass media) in the context of rural development and rural policy $[2,3,4,5,7,8,9,11,12]$, information about Slovakia is still not much available and Slovakia (when being compared, for example, with Poland or Czech Republic) remains a relatively "terra incognita" for the rest of the rural Europe.

\section{Methodology}

There are a couple of quantitative and qualitative conditions for establishment of LAG in Slovakia. LAG area must be (from the geographical point of view) a coherent rural territory formed on the principle of common interests, with a total population in the range between 10,000 and 150,000 and boundaries 
which coincide with those of the municipalities that are partners in the LAG.

In the 2007-2013 programming period 29 Local Action Groups (LAG) have been registered in Slovakia (Fig. 1). Regions covered by these LAGS have been selected for detail comparative inter and intranational analysis of their basic, geographically relevant characteristics by using the individual and ag- gregate statistical data. The results are presented in the form of table (international comparison) and series of the figures (intranational comparison). In the horizontal axes of all figures, the spatial units representing the territories covered by LAGs are marked with numbers (1-29) which are to identify them in Fig. 1. They will be marked identically in the text.

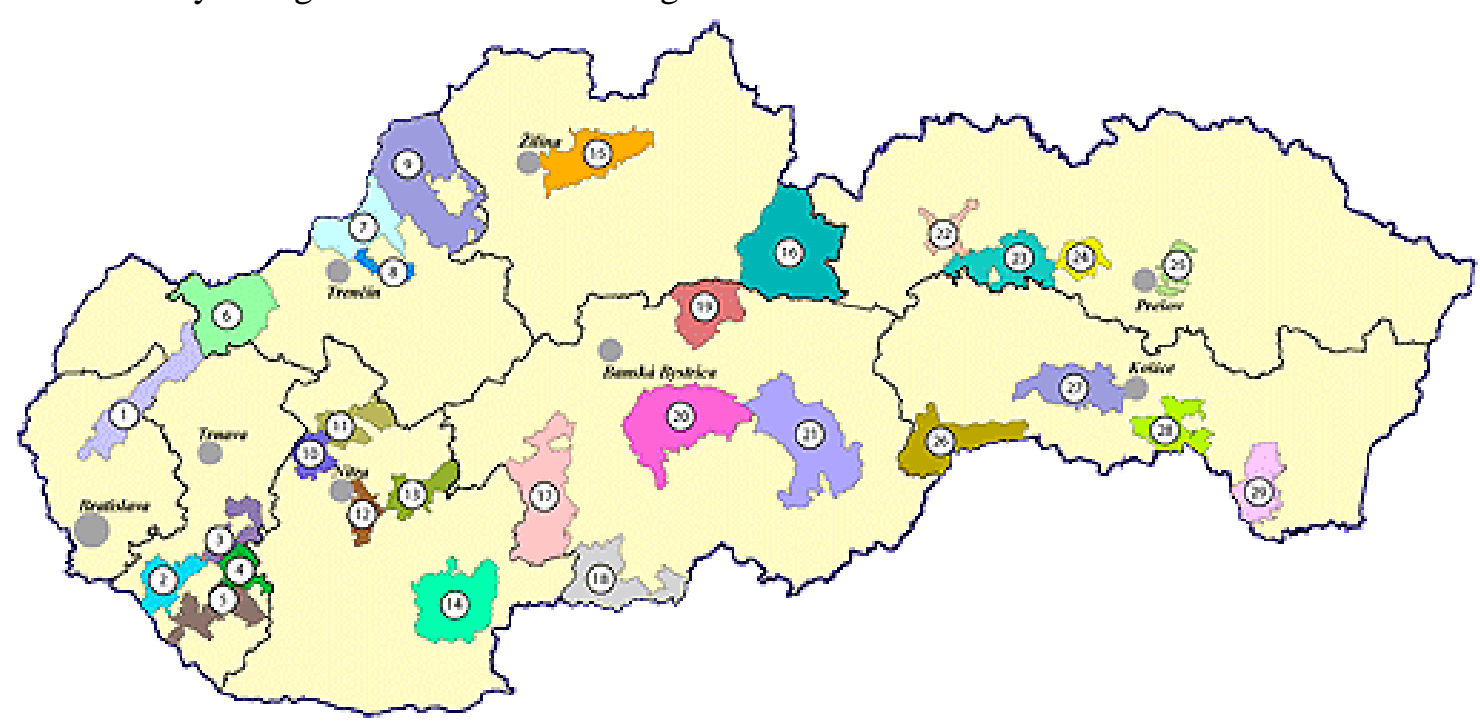

Figure 1: Slovakia: list and geographical positions of registered Local Action Groups in the 2007-2013 programming period [10]

1 - Civic association Podhoran, 2 - Agroprameň, 3 - LAG Dudváh, 4 - LAG Stará Čierna voda, 5 LAG Aqua Paradise - Aquaparadiso - Víziparadicsom, 6 - Kopaničiarsky region - LAG, 7 - LAG Vršatec, 8 - „LAG of microregion Teplička“, 9 - Naše Považie, 10 - Civic Association Microregion RADOŠINKA, 11 - Association of microregion SVORNOSŤ, 12 - Regional association Dolná Nitra c.a., 13 - The civic association for development of microregion „Požitavie - Širočina“, 14 Dolnohronske development partnership, 15 - Civic association "Partnership for LAG Terchovská dolina“, 16 - LAG Horný Liptov, 17 - Civic Association Zlatá cesta, 18 - Partnership Krtíšske Poiplie, 19 - LAG Chopok juh, 20 - Podpolanie, 21 - LAG MALOHONT, 22 - Civic association for regional development Spiš, 23 - Civic Association LAG LEV, c.a., 24 - Partnership BACHUREŇ, 25 - LAG Šafrán, 26 - Civic Association KRAS, 27 - LAG RUDOHORIE, c.a., 28 - LAG HORNÁD SLANSKÉ VRCHY, c.a., 29 - LAG TOKAJ - ROVINA, c. a.

\section{Local action groups in Slovakia: basic characteristics}

\section{International comparison}

Historical process of change in the rural development paradigm with the assistance of the European Union's 'LEADER' programme and establishing of Local Action Groups (as the EU local agencies for rural development) in the individual countries is result of several factors. Differentiated length of their membership in the European Union in liaison with the acceptance and growth of the significance of European policies (as far as the rural development is con- cerned, it mainly is the Common Agricultural Policy - CAP), however, plays a significant role there. The EU's young member states (which also include Slovakia after its accession to EU in 2004), their political representatives, but also ordinary people are facing numerous innovative approaches and have to learn to manage their economic industries and spatial units in a new way or more precisely, to answer the challenges enabling them to enhance the quality of their lives. If they want to meet with success, they must cope with innovative way of thinking and procedures which are not simple at all. That's why the innovative ideas on endogenous rural development and many activities 
performed with good intention are viewed as attractive challenges whose viability is hampered not only by intricate bureaucratic procedures, but inexperience in practical life in connection with insufficient skills and knowledge. The deep-seated way of thinking surviving from the previous socialist regime and the existing prejudices and opinionrelated limitations in establishing publicprivate partnerships (government, civil society and economic sectors) also turns out to be a problem. On top of this, according to Maurel [9] "postcollectivist societies tend to be reluctant to cooperate and act collectively" (p. 516).

The differentiated speed with which a new idea on rural development paradigm change is adopted and accepted depending on the number of years of membership in the EU is documented by Tab. 1. Slovakia (since 2004,), Austria (since 1995) and Ireland (since 1973) are compared to each other from the viewpoints of number, size and significance of the LAGs registered for the period 2007 - 2013. In comparison with older EU members, Slovakia through its value of the indicators compared indicates some kind of embryonic stage of forming the rural partnerships adhering to the advancement of their territories. While in Ireland, the LAGs cover up to $98 \%$ of the territory of the country being home up to 59\% of the Irish population, in Slovakia, LAGs only covered $18 \%$ of the territory of the country being merely inhabited by $11 \%$ of Slovak inhabitants. There are also huge differences in terms of the average size of the LAGs in the countries compared. Simple comparison of Slovakia with for example Ireland clearly shows that the average size of the LAG territory in Slovakia is more than 6 times smaller and the average number of inhabitants per LAG in Slovakia is more than 3 times lower than in the above-mentioned country. The statistically registered differences which indicate the differentiated "action" power of the LAGs in the individual countries have their practical consequences (for example multispectral view of the possibilities of development, higher potential of project preparation, and the like).

Table1: Leader 2007-2013 application in Slovakia (in comparison with Austria and Ireland)

\begin{tabular}{lccc}
\hline LEADER 2007-2013 & Slovakia & Austria & Ireland \\
\hline number of LAGs & 29 & 86 & 36 \\
population in LAGs $(2008)$ & 618,515 & $4,338,542$ & $2,501,510$ \\
total area of LAGs $\left(\mathrm{km}^{2}\right)$ & 8,995 & 73,304 & 68,882 \\
population/LAG & 21,328 & 50,448 & 69,486 \\
$\%$ of total national area & 18 & 88 & 98 \\
\% of total national population & 11 & 52 & 59 \\
\hline
\end{tabular}

Source: $[3,10]+$ own calculation

\section{Intranational comparison}

Along with relative geographical locations of the single LAGs, Fig. 1 also shows not only the differentiated size and shape of the territories covered by them, but also their relations to regional boundaries. The territories covered by the LAGs constitute for us territorial units which we are going to compare according to the basic, geographically relevant attributes.

Size of LAGs

The fundamental attribute of the territory covered by LAG is the number of inhabitants. According to criteria having been adopted to obtain the status of LAG,

the rural area has to be inhabited by 10,000 to 150,000 inhabitants. LAG should mainly involve rural municipalities, but also small urban municipalities whose population does not exceed 20,000, being authorised to accept financial support. Urban municipallities with a population over 20,000 people can be members of LAG but they are excluded from the financial support acceptance. These rules are crucial for population size of LAGs in Slovakia (Fig. $2)$. 


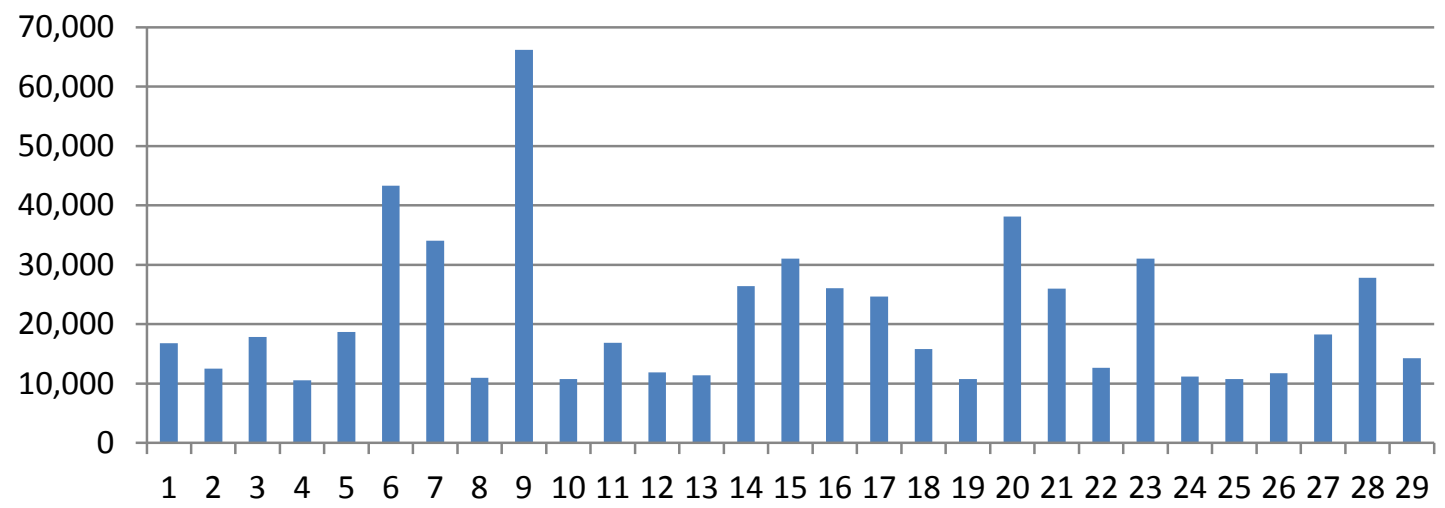

Figure 2: LAGs in Slovakia: number of inhabitants

Most of LAGs meet the minimum criteria laid down on their size. Out of a total of 29 LAGs, almost two thirds (18) are below average in size; 12 LAGs even do not reach the size of 15,000 inhabitants. "Naše Považie" (LAG no. 9) is the biggest LAG involving Púchov - the district town with population over 18,000 . Interestingly, the territories of up to 11 LAGs include urban municipality or urban municipalities (LAGs no. $6,7,8,9,14,16,17,20,21,23$, and 27). As a rule, they are small cities (population of only 5 out of a total of 17 urban municipalities exceed 10,000) which, however, from the viewpoint of commuting to work play a prominent role in the local labour markets. Some of them even have the status of a district town and thanks to concentration of employment opportunities they are a natural core of functional urban region.

Differences in the sizes of the individual LAGs exist not only due to the differences in sizes of the rural and urban municipalities represented (Fig. 3), but also due to the differentiated numbers of them (Fig. 4). While the number of the municipalities represented varies from 4 (LAG no. 8) to 44 (LAG no. 9), the average municipality size starts with 466 inhabitants (LAG no. 18) to 2,745 inhabitants (LAG no. 8).

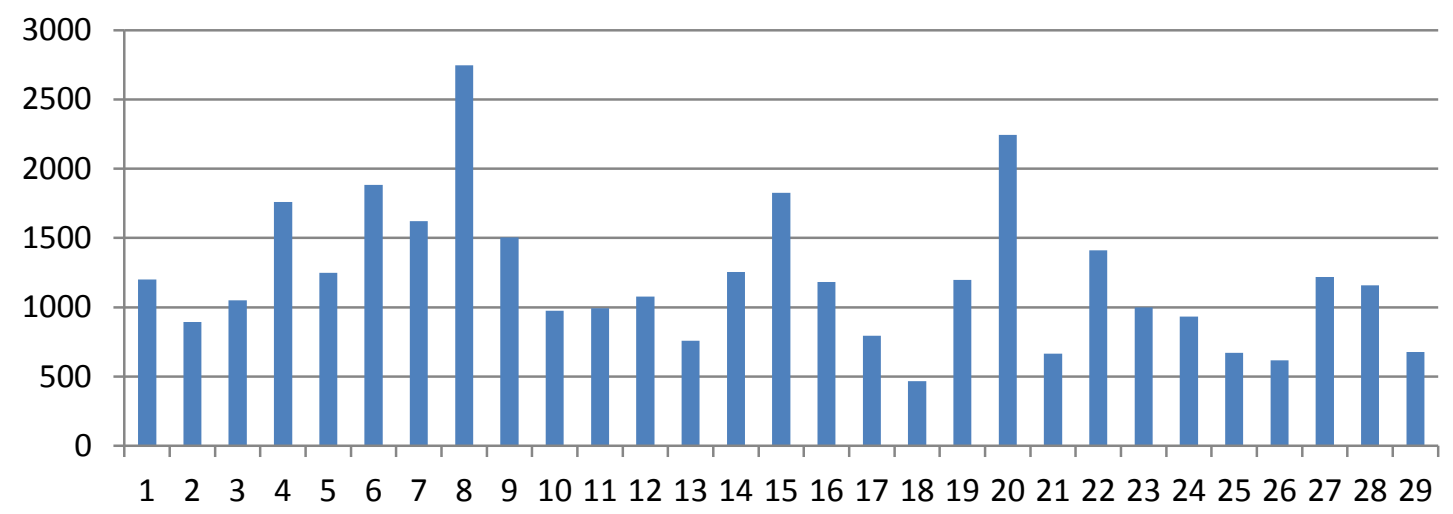

Figure 3: LAGs in Slovakia: average number of inhabitants per municipality 


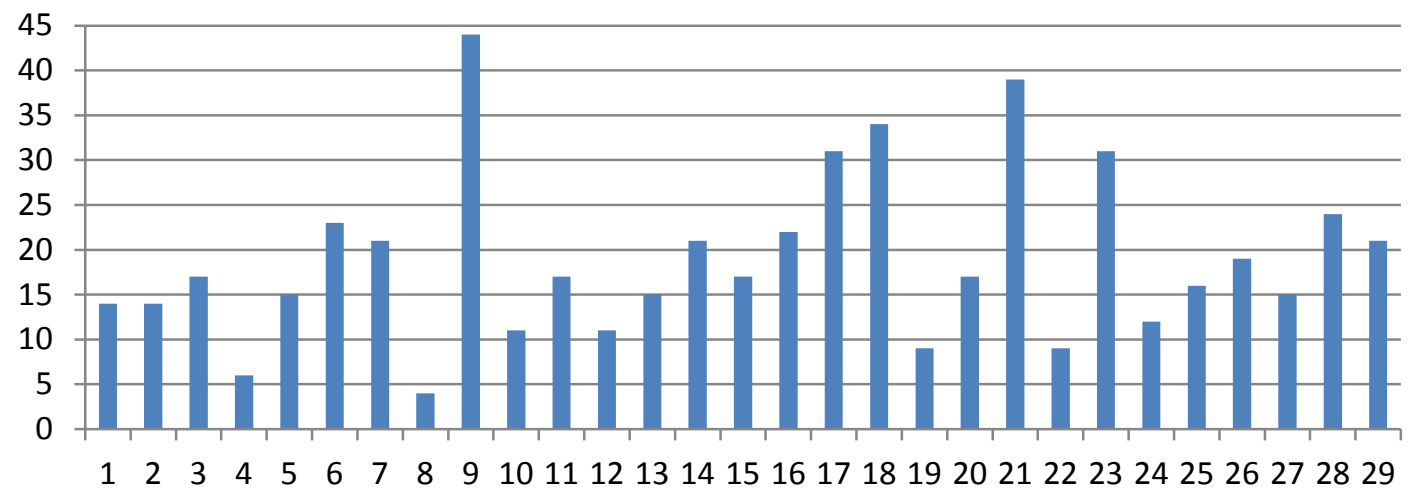

Figure 4: LAGs in Slovakia: number of municipalities

Huge differences between LAGs can also be seen in the size of their territories (Fig. 5). The area of LAG no.16 is more than 10 times larger than that of the LAG with the least number, but with the biggest average municipality size - no.8 "Microregion Teplička". All numerical values are impor- tant for deeper understanding and explanation the differences in the scope of the functioning (e.g. size and character of intra-LAG interactions, public-private relations, level of financial support, etc.) of territories covered by the individual LAGs.

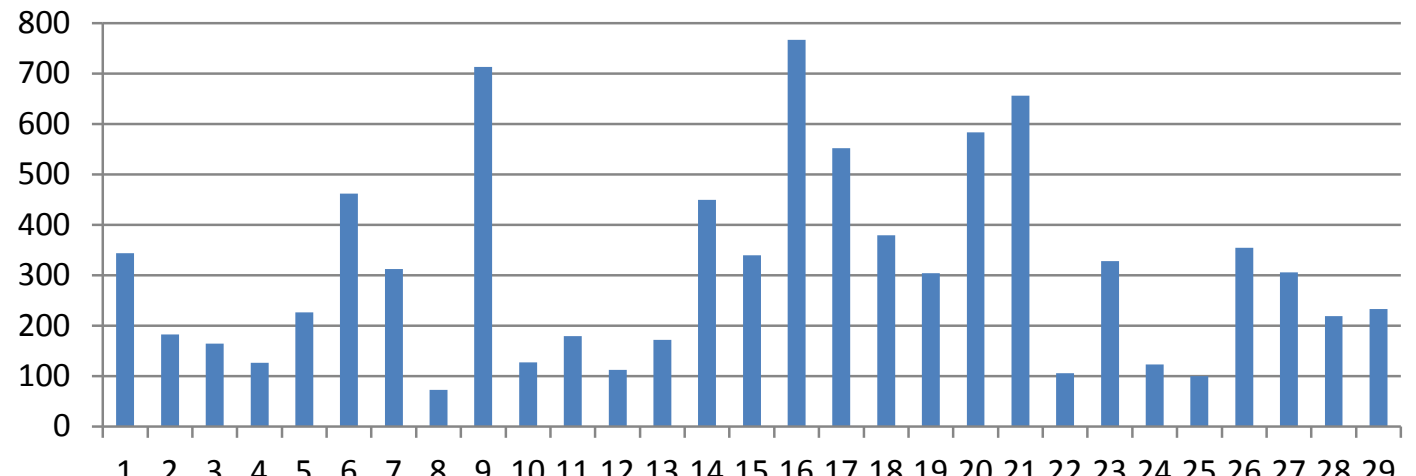

Figure 5: LAGs in Slovakia: territorial size in $\mathrm{km}^{2}$

$L A G$ territory shapes and their relation to administrative boundaries

When taking a closer look at Fig. 1 we can discover that in some cases, the shapes of the individual LAG territories are considerably irregular in shape. This is caused not only by the willingness to voluntarily join the alliance of municipalities participating in carrying out of rural strategy, but also by the spatial organization of the society itself where the occurrence of numerous, small, rural municipalities is accompanied by quite a rare occurrence of bigger towns (within the meaning of rules pertaining to the possibility to receive financial support which constitutes one of key ones for establishing LAGs we are talking about towns with a population that exceed 20,000 inhabitants). These bigger towns, natural regional and administra tive cores, mainly concentrating rural and urban commuting due to the attractive job offer have been excluded from the LAG territories. In some cases, where LAG consists of rural municipalities closely surrounding such bigger town, a territory extremely irregular in shape is created with broken spatial functionality and adequate consequences on the intra-LAG commuting values (LAGs no. 3 and 9). In some cases, however, a single (successful) rural municipality has not been included in LAG, whereby it is breaking its territorial integrity (LAG no. 23).

LAG establishing under a significant influence of administrative boundaries is a specific problem. Except for LAG no. 1, the administrative boundary between regions (NUTS 3) constitutes a barrier in joining rural municipalities to put the common strat- 
egy of development into practice. The boundaries of LAG territories closely follow the regional boundaries. When going to lower hierarchical level - district (LAU 1), the problem has partially been overcome. In 11 LAGs, stakeholders from two districts were able to come to an agreement on a common strategy of development. As far as the individual municipalities are concerned, however, significant disproportionality prevails - in LAG no. 15, the proportion of the participating municipalities between two districts is $16: 1$. It is interesting that, in any of the cases, despite spatial proximity, LAG have not been created in the territories of 3 districts.

On the other hand, the municipalities located in the territory of one single district are members of several LAGs. Municipalities situated in the districts of Dunajská Streda (LAGs no. 2 and 4), Trenčín (LAGs no. 7 and 8), Prešov (LAGs no. 24 and 25) and Košice-okolie (LAGs no. 27 and 28) have joined into 2 LAGs. Rural municipalities located in the district of Nitra which could, without its centre (the regional city of Nitra), create a single LAG with a population less than 100,000 are members of 3 LAGs (LAGs no. 10, 12, and 13) which are quite small. A number of very important questions arises regarding mainly perception of LAG itself and its objectives. Does the LAG constitute and maintain its original purpose for its participating members and general public, that is, being an animator assisting with the cooperation of the local actors and entity putting into practice the rural development strategy, or is the LAG more perceived as the regional subsidy agency redistributing the finances [2].

\section{Conclusion}

Creating of LAGs in Slovakia has predominantly been initiated by the representatives of the local government (mayors of municipalities); in some cases, the inevitable share of private and civic sectors required is often a result of their social networking (relatives or friends). This type of partnership can theoretically produce a specific group of persons involved separating themselves from the group of local residents showing little loyalty to the developmental priorities of the existing partnerships presented. Unfortunately, this idea which infringes the fundamental principle of the LEADER initiative, consisting in accentuating the participation of all strata of the local population in rural development, is not only a theoretical speculation specific for Slovakia [5, 11].

Stakeholders from territories (often missing functional linkages) spontaneously formed basing on the interest of their representatives to join forces and prepare Integrated plan of territorial development could be motivated by multifarious factors. But the possibility to obtain the "Local Action Group" status and to draw down EU funds is designated as one of the fundamental motivations. However, when the LAGs as integral part of LEADER programme (as the representative of the endogenous rural development) were established at the beginning of the 1990s, their essential purpose was to activate the local people to participate in the activities and in the decision-making regarding the development of the territory where they live. The current shift from the original and ideal perception, understanding and interpretation of the key subject of the endogenous rural development to the more pragmatic one is documented by Boukalová et al. [2]. Czech authors state that LAG is presented in the masmedia almost exclusively as the regional subsidy agency redistributing the finances. We are feeling (we have no results of concrete scientific research) something similar we could say about role of LAG in the Slovak neo-liberal society.

\section{Acknowledgement}

This article was prepared as part of the Project No. 2/0035/15 „Development trajectories of localities and regions - product of sector and spatial policies, territorial capital and decisions ", funded by the Slovak VEGA Grant Agency. The author thanks to the Slovak VEGA Grant Agency for its financial support. Special thanks go to Ms. Iveta Tabladová for her help with translating this article into English. 


\section{References}

[1] Ashley, C. \& Maxwell, S. Rethinking rural development, Development Policy Review, 2001, vol. 19, pp. 395-425.

[2] Boukalová, K. \& Kolářová, A. \& Lošták, M. Tracing shift in Czech rural development paradigm (Reflections of Local Action Groups in the media), Agricultural Economics Czech, 2016, vol. 62, pp. 149-159.

[3] Dax, T. \& Strahl, W. \& Kirwan, J. \& Maye, D. The Leader programme 2007-2013: Enabling or disabling social innovation and neo-endogenous development? Insights from Austria and Ireland, European Urban and Regional Studies, 2016, vol. 23, pp. 56-68.

[4] Esparcia, J. Innovation and networks in rural areas. An analysis from European innovative projects, Journal of Rural Studies, 2014, vol. 34, pp. 1-14.

[5] Furmankiewicz, M. \& Thompson, N. \& Zielinska, M. Area-based partnerships in rural Poland: the post-accession experience, Journal of Rural Studies, 2010, vol. 26, pp. 52-62.

[6] Guinjoan, E. \& Badia, A. \& Tulla, A.F. The new paradigm of rural development. Theoretical considerations and reconceptualization using the "rural web", Boletín de la Asociación de Geógrafos Españoles, 2016, No. 71, pp. 495-500.

[7] Kovách, I. LEADER, a new social order, and the Central and Eastern European countries, Sociologia Ruralis, 2000, vol. 40, pp. 181-189.

[8] Lopolito, A. \& Nardone, G. \& Sisto, R. Towards a comprehensive evaluation of Local Action Groups in LEADER programmes, New Medit, 2011, vol. 10, pp. 43-49.

[9] Maurel, M.-C. Local development stakeholders and the European model: Learning the LEADER approach in the new member states. Sociologický časopis/Czech Sociological Review, 2008, vol. 44, pp. 511-529.

[10] Národná siet' rozvoja vidieka, National Network for Rural Development, Slovakia (http://nsrv.sk)

[11] Navarro, F.A. \& Woods, M. \& Cejudo, E. The LEADER initiative has been a victim of its own success. The decline of the bottom-up approach in rural development programmes. The cases of Wales and Andalusia, Sociologia Ruralis, 2016, vol. 56, pp. 270288.

[12] Ray, C. The EU LEADER Programme: rural development laboratory. Sociologia Ruralis, 2000, vol. 40, pp. 163-171. 